\title{
AN ANALYSIS OF AIR PARTICULATES \\ GENERATED IN THE BOSTON SUMNER TUNNEL \\ AND ENVIRONS
}

by
Alexander A. P. Pszenny*
and
Irving J. Russe11
Department of Chemistry
BOSTON COLLEGE

Chestnut H111, Massachusetts

June 1974

Prepared for Contract Number AT) 11-1)-3015

ATOMIC ENERGY COMMISSION

CHICAGO OPERATIONS OFFICE

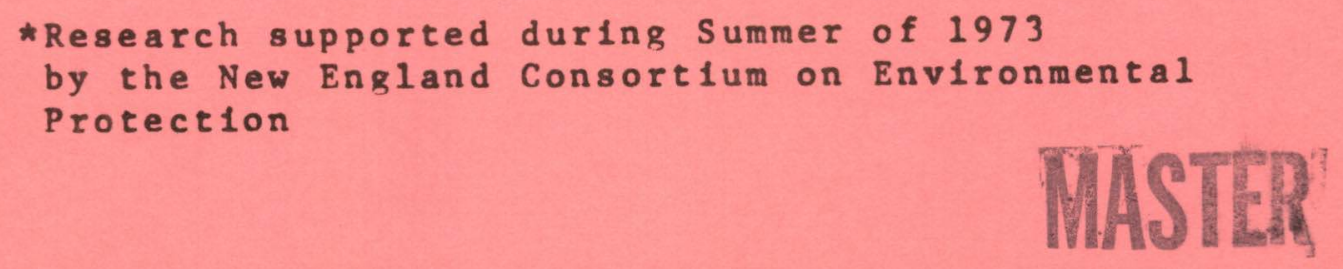




\section{DISCLAIMER}

This report was prepared as an account of work sponsored by an agency of the United States Government. Neither the United States Government nor any agency Thereot, nor any of their employees, makes any warranty, express or implied, or assumes any legal liability or responsibility for the accuracy, completeness, or usefulness of any information, apparatus, product, or process disclosed, or represents that its use would not infringe privately owned rights. Reference herein to any specific commercial product, process, or service by trade name, trademark, manufacturer, or otherwise does not necessarily constitute or imply its endorsement, recommendation, or favoring by the United States Government or any agency thereof. The views and opinions of authors expressed herein do not necessarlly state or reflect those of the United States Government or any agency thereof. 


\section{DISCLAIMER}

Portions of this document may be illegible in electronic image products. Images are produced from the best available original document. 
AN ANALYSIS OF AIR PARTICULATES GENERATED IN THE BOSTON SUMNER TUNNEL AND ENVIRONS

\author{
by \\ ALEXANDER A. P: PSZENNY* \\ and \\ IRVING J RUSSELL \\ DEPARTMENT OF CHEMISTRY \\ BOSTON COLLEGE \\ CHESTMUT HILI, MASSACHUSETTS \\ * RESEARCh SUUPForTEd DURING SUMMER \\ OF 1973 BY. THE NEW ENGLAND \\ CONSORTIUM ON ENVIRONMENTAL \\ PROTECTION
}

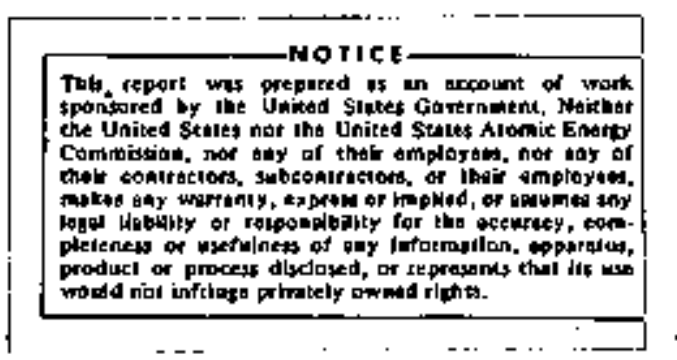

4 


\section{INTRODUCTION}

This study of air particulates in the sumner runnel was designed to better define the chemical composition of inorganic constituents generated by automotive activity. The tunnel was chosen for study because of anticipated higher than normal concentrations of automobile products inside relative to those outside.

The long term objective is to develop a procedure for resolving a mixture of air particulates into its individual source components in a realistic way. To do this adequately requires detailed information on individual sources among the more important of which are gasoline combustion products and other substances generated by automotive activity.

\section{EXPERIYENTAL}

The Sumner Tunnel runs approximately whw from its entrance poxtal in East Boston to its exit portal in downtown Boston. portalto-portal distance is 2061 meters or 1.07 miles. Two staplex model TFlA and one Bendix model 550 high-volume aix samplexs stationed on the walkway inside the tunnel. at approximately 330 meters, 450 meters, and 575 meters respectively from the exit portal.

A second Bendix instrument was positioned 40 meters from the exit portal at sidewalk level next to the guard station on the plaza into which tunnel traffic empties.

Four sets of particulate samples were collected on $10 \mathrm{~cm}$ diam Whatman \#41 filters for approximately 4 hour periods on 30 and 31 August 1973. Air volume passed per sample averaged 115 cubic meters. Data on the number of venicles which passed through the tunnel aring the sampling periods was provided by tunnel authorities and averaged 2144 vehicles per hour. (Table 1).

Whatman \#4I was chosen for use as a collection matrix due to its relatively low blank values for most elenents (Dams, et. al.. 1972). Filters were dried, desiccated and weighed before and after 
exposure and total particulate weights were determined. One half of each filter was ashed at $450^{\circ} \mathrm{C}$ in a muffle furnace; the ash was welghed to the nearest microgram on a cahr Electrobalance and sealed in 1 cm outside diameter polyethylene capsules. The capsules were packed into a "rabbit" and irradiated at the MIT Reactor for 8 hours in a flux of $2 \times 10^{13}$ neutrons per square eentimeter per second. Individual elements were assayed by High-resolution gamma-ray spectroscopy using a $30 \mathrm{kC} \mathrm{Ge(Li)} \mathrm{detector.} \mathrm{Spectra} \mathrm{were} \mathrm{stored} \mathrm{on}$ magnetic tape and reduced by computer. Data were obtained for 18 elements.

Two-thirds of each remaining filter was ashed at roon temperatuxe using RF generated atomic oxygen in a Tracerlab model LTA600 low temperature asher. The ash was weighed and decomposed in hot concentrated $\mathrm{HCl}$ and $\mathrm{HNO}_{3}$, then made up to $10 \mathrm{ml}$ volume with distilled $\mathrm{H}_{2} \mathrm{O}$. The resulting solution was approximately $\mathrm{I}_{\mathrm{H}}$ in $\mathrm{HNO}_{3}$. Eight elements were assayed by Atomic Absorption Spectroscopy including six in common with the neutron activation analysis, for comparison purposes.

One-sixth of each sample remains unprocessed to date and will be used to check on some inconsistent results, as discussed later.

\section{RESULTS}

Results of these analyses are summarized in Tables 2 and 3.

The composition of the samples taken within the tunnel differs in major respects from that outside only in the concentrations of $\mathrm{Pb}$ and $B r$, both of which are contributed directly by automotive exhausts (Midaleton, 1971).

However, lead and bromine concentrations in the outside air were also substantial and indicate that air within the tunnel is being efficiently exchanged. In Table 2 is given the composition of the tunnel samples and of the outside air, expressed as parts per million in mineral ash, averaged for three sets of samples. Table 3 contains the averaged concentrations of elements in air in units 
of nanograms per cubic meter. The Pb dat were obtained by Atomic Absorption spectroscopy, all other elements were obtained by Neutron Activation Analysis using the U.S. Geological Rock Standard w-1 as reference. standard deviations are presented to indicate the variations among samples. Also included in each table is a t-test of the means "plaza" vs "tunnel", at the $95 \%$ confidence level for each element. A "YES" signifies that the means are statistically different at this confidence level; a "No" signifies that they are not.

\section{DISCUSSION}

Pb and Br

The low concentrations of $\mathrm{Br}$ in both the tunnel and plaza samples is clearly anomalous. The $\mathrm{Pb} / \mathrm{Br}$ ratio is about $40: 1$, whereas one expects about $25: 1$ based on the composition of "PbBrcl". As noted elsewhere, this ratio is raxely found (Robbins and snitz 1972), since Br is known to be lost by photolytic decomposition (Pierrard, 1969), diffusion processes, or both. We conclude that in our method of sample preparation by muffle furnace ashing at $450^{\circ} \mathrm{C}$ the majority of the Br was lost by diffusion and vaporization. However, we note that the ratio of Na to Br is about 14, which suggesta that the $\mathrm{Br}$ is from sources in addition to sea water, for which the value is about 165 .

The concentration and gaseous fraction of bromine in cambridge air was examined (Moyers, et.al., 1972). They found .12-.45 $\mathrm{Mg}^{\mathrm{M}} \mathrm{M}^{3}$ compared to .12-.94 $\mathrm{Mg} / \mathrm{m}^{3}$ in the particulate form. particulate $\mathrm{V}$ was . 08-1.32 $\mathrm{Mg} / \mathrm{m}^{3}$ and $P b$ varied from .4-3.7 ug/ $/ \mathrm{m}^{3}$. The ratio of total $\mathrm{Br}$ to $\mathrm{Pb}$ varied with wind direction being typically.32 with $\mathrm{C}$ the wind from a Westerly direction, and as high as .62 with the wind from an Easterly direction. The authors attribute this to free Bromine from a maritime source.

This accords with the results of the university of Maryland Group who observed that Br and cl distributions with particle size. 
in the Baltimore Harbor Tunnel are bi-modal with a sagll-particle component resulting from combustion of leaded gasoline and a largeparticle component consisting of particles present in intake air, possibly enriched in Br and $c 1$ by gas-phase surface attachment (Gordon, et. a1., 1973). We intend to check our resuts by runing a second neutron activation analysis on the remaining sample sections prepared by low-temperature ashing methods.

$\underline{\mathrm{Zn}}$

The $\mathrm{Pb} / \mathrm{Zn}$ ratio is of some interest. In this study it is quite variable (6.8 in the plaza and 25 in the tunne1). In a series of particulate samples taken on the roof of the chemistry building at Boston college. (February-March 1970), the ratio averaged 4.9. The $\mathrm{Pb}$ and $\mathrm{Zn}$ were almost perfectly coxrelated for this 40day period suggesting an automotive related source.

It is possible that many of the variations noted in elemental ratios in polluted air are due to particle size effects. The B.C. rooftop samples, with an enrichment of $\mathrm{zn}$ with respect to Pb may indicate that a greater fraction of the $\mathrm{zn}$ is more easily suspended. than $\mathrm{Bb}$.

\section{The possible Significance of Resuspension}

The high concentrations of particulates found outside the tumel during this particular sampling episode were undoubtedly related in part to the stable atmospheric conditions which prevailed. It is probable that much of the particulate found near ground level is material resuspended by moving vehicles. We note that the composition of the material both outside and inside the tunnel has the chemical composition of a polluted soil, $j . e$. , the typical concentrations of substances found in the soil augmented by $\mathrm{Sb}, \mathrm{Zn}, \mathrm{Pb}$ and $\mathrm{Br}$. of these, only $\mathrm{Pb}$ makes any significant contribution to the total weight of the aample. 
In the B.C. study we noted an inverse correlation between the concentrations of the "sofl" elements typified by Fe, se and ce and the automotive exhaust elements typified by Br, on a day to day basis. on days characterized by brisk winds, generally from the west, the concentrations, of $2 n, \mathrm{~Pb}, \mathrm{Sb}$ and $\mathrm{Br}$ were usually somewhat decreased relative to those of the $\mathrm{Fe}, \mathrm{Ce}$, Sc group; the reverse situation obtained when the'winds were light and from a northerly or easterly direction. Since the sampling station was elevated (4th floor level) apparently the earth crustal elements were found in high concentrations on $l_{y}$ when the wind could. loft larger resuspended particles to greater altitudes. The increased atmospheric turbulence associated with stronger winds also effected a dilution of the automotive products.

If this view is correct, the automotive pollution term : should include these "indirect" contributions to the particulate burden as well as direct ones.

It is of interest to compare our results with those of an earlier, more detailed study of air quality in the sumner Tunnel in July and september 1961 (Larsen and Konopinski, 1962). : We report eight elements in common: Sb, Cr, Co, Cu, Fe, Pb, Mn, Zn. The authors of the earlier study present theix results for individual. elements as indices defined as concentration ratios: ([outlet]/[inlet] $)$ - 1. Selected data are given in Table 4 .

Table 4 indicates that the concentrations of the elements found in comnon are always somewhat higher in the outlet air of the earlier study (a factor of 2.5 to 4 for most elements). We further note that the concentrations of the inlet air in the 1961 stuay for $\mathrm{Pb}$.is significantly lower than that in the 1974 study. This combination of circumstances certainly renders the earlier study more appropriate for discerning the contributions due to automotive activity. 
The average concentration of $\mathrm{pb}$ in the tunnel is $11 \mu \mathrm{g} / \mathrm{m}^{3}$ compared to $4 \mu \mathrm{g} / \mathrm{m}^{3}$ of air in the plaza. Thus, the net $\mathrm{Pb}$ expelled from the tunnel each minute is (21-4) $Q$ where $Q$ is the intake and outlet rate in cubic meters per minute. A traffic count during our study gave an average of 2144 vehicles per hour or 35.7 vehicles per minute. The Boston half of the tunnel is $0.55 \mathrm{mile}$ long, therefore the number of vehicle miles accumulated per minute is 19.6. Using an estimate of $35,000 \mathrm{pg} \mathrm{Pb} /$ vericle-mile derived in the earlier study (Larsen and konopinski, 1962) leads to $3500 \times 19.6=6.86 \times 10^{5} \mathrm{\mu g}^{\mathrm{PO}} / \mathrm{min}$ introduced into the tunnel, since we are dealing with a closed system (if any piston effect is ignored) and a steady-state situation in which the amount of $\mathrm{Pb}$ generated by automotive activity is being removed at the same rate it is introduced, $(11-4) Q=6.86 \times 10^{5}$ and $Q=9.8 \times 10^{4} \mathrm{~m}^{3} / \mathrm{min}$. The total. volume of the Boston half of the tunnel is $4.93 \times 10^{4} \mathrm{~m}^{3}$. Therefore $Q / \mathrm{N}$ is of the order of $2 \mathrm{~min}^{-1}$ which is about 4 times higher than the 1962 value of 0.5 .

We are informed by tumnel authorities that the maximum flow rate is presently $2.79 \times 10^{4} \mathrm{~m}^{3} / \mathrm{min}$. (see Table 5) compared to $1.73 \times 10^{4} \mathrm{~m}^{3} / \mathrm{min}$. in 1962 . This factor of 1.6 along with other differences between Larsen and konopinski's study and ours (such as different traffic flow, sampler locations, and atmospheric conditions) can in part account for the factor of 4 difference $Q / N$ values obtained. However the unaccounted for factor of 2.5 difference is troublesome.

\section{SUUMMARY}

A series of air particulate samples was collected in the 1.1 mile long Boston Sumner Tunnel on 31 August 1973. Analysis of the samples by neutron activation and atomic absorption yielded data for 18 elements.

Those found to be definitely correlated with automotive activity are $\mathrm{Pb}$ and $\mathrm{Br}$. $\mathrm{Cu}$, co and $\mathrm{Mr}$ show a negative correlation. 
Data from an earlier study in our laboratory showed an and $5 b$ correlated well with $B F$ suggesting an automative source for these elements. No confirmation of this was obtained in this study. Resuspension is postulated as an important consequence. The concentrations of earth crustal elements were in general slightly less in tunnel air. A possible reason for this is that the higher concentration of $\mathrm{Pb}$ necessarily causes concentrations of other constituents to decrease (even at the atomfor-atom level) to maintain. a mass balance.

A comparison of our Po data with that of Larsen and Konopinski, 1962 led to a supposition that ventilation capacity had been somewhat increased since 1962. This was confirmed by tunnel authorities.

We quote from Ter Haar (1972) with respect to the overall problem of automative pollution: "A reveiw of the available published information on particulate emission gives some idea of automotive contribution to total man-made-atmospheric particulate. The contribution of the automobile varies with particulate load from values as low as $3 \%$ in a "heavy particulate" city (St. Louis) to $37 \%$ in a basically clean area (LOs Angeles) with the average for the united states being about 1.a\%. NASN data for the lead content of total suspended atmospheric particulate shows, for 27 cities where data are available that on $1_{y} 0.51 \%$ of the particulate is lead. Thus, it seerus we are being asked to control, at a large cost, a very small portion of the total atmospheric particulates." (underlined added) .

This statement, by a representative of the Ethyl corporation, ignores several important factors. His chojce of Los Angeles as a "basically clean area" is somewhat ironic considering the bad name Los Angeles has given the automobile. As the Sumer Tunnel study by Larsen and Konopinski shows, the contribution of carcinogenic constituents of the particulate product (benzpyrene) is not insignificant. Thus Ter Haar chooses to ignore the quality factor. As to lead, only epidemilogical studies in the future will reveal the true impact of this substance, present in concentrations of $1-5 \mathrm{ug} / \mathrm{m}^{3}$ in our city air. But more importantly. 
in the context of particulete losding, in city streets. It ig probable that the automobile is responsible indirect! $y$ because of its dynamic resuspension action for a much higher percentage of the total particulate burden than noted by Ter Harr on the basis of direct automotive emissions.

We wish to express sincere appreciation to $\mathrm{Mr}$. Theodore H Ridex of Weston Observatory and the New Englend consortium on Environmental Protection for his support of this study and to the officials of the Massachusetts Turnpike Authoxity, especially Mr. William P. Driscoll superintendont of Tunne $1.5, \mathrm{Mr}$. John $J$. Downing and Mr. Willism o'zewski. stoff engineers, for their courtesy and invaluable assistance during the eampling phase. This vork was supported in part by the U.s. Atomic Energy Commission under contract number AT(1)-1) 3015 
TABLE 1

SAMPLING PERIOD

SUMNER TUNNEL TRAFFIC FLOW

31 AUGUST 1973

HOJR (EASTERN

0600 to 0700

0700 to 0800

0800 to 0900

0900 to 1000

1000 to 1100

1200 to 1200

1200 to 1300

1300 to 1400

1400 to 1500

1500 to 1600

1600 to 1700

1700 to 1800

1800 to 1900
NIMEER OF

VEAICLFS PASSED

1980

2760

2568

1936

is 2168

1894

1934

2290

2104

2301

2013

1699

2156 
TABLE 2

PARTS PER MILLION IN MINERAL ASH

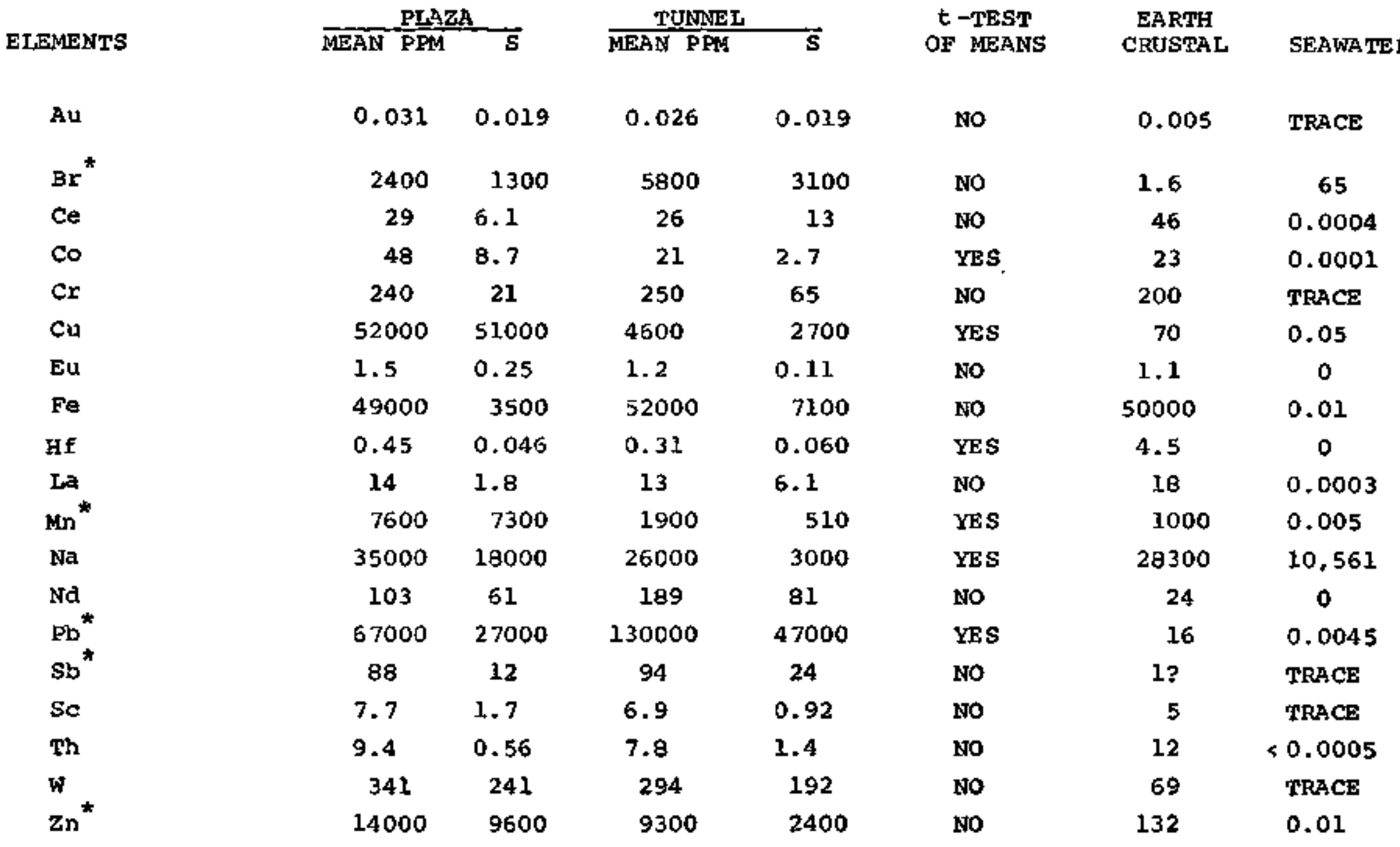

*Suspected to be indices of automotive activity 
TABIE 3

$\mathrm{ng} / \mathrm{m}^{3}$

\begin{tabular}{|c|c|c|c|c|c|}
\hline \multirow[b]{2}{*}{ ELEMENT } & \multicolumn{2}{|c|}{ PLAZA } & \multicolumn{2}{|c|}{ TUNNEL } & \multirow[b]{2}{*}{ t-TEST } \\
\hline & $\begin{array}{l}\text { MEAN } \\
\mathrm{ng} / \mathrm{m}^{3}\end{array}$ & 10 & $\begin{array}{l}\text { MEAN } \\
\mathrm{ng} / \mathrm{m}^{3}\end{array}$ & $\sigma$ & \\
\hline $\mathrm{Au}$ & 0.0017 & 0.00092 & 0.0019 & 0.0010 & No \\
\hline $\mathrm{Br}$ & 130 & 65 & 440 & 220 & so \\
\hline $\mathrm{Ce}$ & 1.6 & 0.29 & 2.1 & 2.7 & No \\
\hline co & 0.27 & 0.053 & 0.68 & 0.95 & so \\
\hline $\mathrm{Cr}$ & 14. & 36 & 19. & 6.5 & NO \\
\hline $\mathrm{Cu}$ & 2800 & 2500 & 360 & 110 & YES \\
\hline $\mathbf{E} \mathbf{u}$ & 0.082 & 0.0059 & 0.088 & 0.026 & No \\
\hline $\mathrm{Fe}$ & 2800 & 460 & 3900 & 1200 & No \\
\hline Hf & 0.022 & 0.0022 & 0.025 & 0.0074 & No \\
\hline $\mathrm{La}$ & 0.79 & 0.21 & 1.0 & 0.62 & No \\
\hline Mn & 400 & 350 & 160 & 50 & YES \\
\hline $\mathrm{Na}$ & 1900 & 750 & 1800 & 370 & No \\
\hline Nd & 5.6 & 2.6 & 14 & 11. & no \\
\hline $\mathbf{P b}$ & 4000 & 2400 & 11000 & 1700 & YES \\
\hline$s b$ & 5.0 & 1.2 & 6.9 & 1.8 & No \\
\hline Sc & 0.43 & 0.017 & 0.51 & 0.15 & NO \\
\hline Th & 0.53 & 0.071 & 0.60 & 0.22 & No \\
\hline w & - 19. & 11. & 25. & 14. & No \\
\hline $\mathrm{Zn}$ & 870. & 700 & 670 & 230. & No \\
\hline
\end{tabular}


TABLE 4

COMPARISON OF SUMNER TUNNEL AIR QUALITY

1962 vs 1973

\begin{tabular}{|c|c|c|c|c|}
\hline 'ELEMENT & $\underset{\text { INDEX } 1962}{\text { Largen \& Konopinski }}$ & $\begin{array}{l}\mathrm{ng} / \mathrm{m}^{3} \\
\text { (outlet) }\end{array}$ & $\begin{array}{l}\text { INDEX I973 } \\
\text { This study }\end{array}$ & $\begin{array}{l}\text { ng } / m^{3} \\
\text { Tunnel }\end{array}$ \\
\hline co & 0.10 & 22 & 1.5 & 0.68 \\
\hline $\mathrm{Cr}$ & 0.47 & 128 & 0.36 & 19. \\
\hline $\mathrm{Cu}$ & 3.15 & 278 & -0.87 & 360 \\
\hline $\mathrm{Fe}$ & 9.33 & 23400 & 0.39 & 3900 \\
\hline Mn & 1.66 & 133 & -0.60 & 160 \\
\hline $\mathrm{Pb}$ & 39.5 & 44500 & 1.8 & 11000 \\
\hline sb & 0.11 & 170 & 0.38 & 6.9 \\
\hline $\mathrm{z}_{n}$ & $0.4 \mathrm{~B}$ & 2248 & -0.23 & 670 \\
\hline
\end{tabular}


TABLE 5

SUMNER TUNNEL VENTILATION SYSTEM

FLOW RATES, 31 AUGUST 1973

BOSTON

6-7 A.M.

7-10 A.M.

10-11 A.M.

$285,000 \mathrm{cfm}$ EXHAUST

280,000 cfm INTAKE

11 A.M. -6 P.M. B55,000 cfm EXHAUST

$840,000 \mathrm{cfm}$ INTAKS

6-7 P.M.

BOSTON

EACH EXHAUST FAN:

LOW-71, 250 $\mathrm{efm}$

HIGH-142,500 $\mathrm{cf}_{\mathrm{TI}}$

EACH INTAKE BLOWER:

LOW $-70,000$

HIGH $-140,000$
$183,000 \mathrm{cfm}$ EXHAUST

LOW $-44,750$

E. BOSTON

$45,750 \mathrm{cfm}$ EXHAUST

$44,750 \mathrm{cfm}$ INTAKE

$457,500 \mathrm{cfm}$ EXHAUST

$447,500 \mathrm{cfm}$ INTAKE

$179,000 \mathrm{cfm}$ INIAKE

$549,000 \mathrm{cfm}$ EXHAUST

$537,000 \mathrm{cfm}$ INTAKE

$274,500 \mathrm{cfm}$ EXHAUST

268,500 efm INTAKE

E. BOSTON

LOW-45, $750 \mathrm{cfm}$

HIGH-91,500 cfm

HIGH $-89,500$

PRIOR TO 1963, THE BOSTON VENTILATION CAPACITY EOUALED THE EAST BOSTON CAPACITY. 
Dams, R., Rahn, K.A., Winchester, J.W., Evaluation of Eilter Materials and Impaction Surfaces for Nondestructive Neutron Activation Analysis of Aerosols, Env. Sci. \& Tech., 6 (5), 44l-448 (1972).

Gordon, G.E., et. al., Study of the Emmissions from Major Air Pollution sources and their Atmospheric tnteractions, first Year Progress Report, University of Maryland Department of Chemistry and Institute for Fluid Dynamics and Applied Mathematics, College park, Maryland. 20742 .

Larsen, R.L., Kunopinski, V.J., Sumper Tunnel Air Quality, Arch. Env. Res.. ‥

Middleton, J.T.. Amer. Sci., 59, (2), 188-94 (1971).

Moyers, J.I., zoller, W.H., Duce, R.A., Hoffman, G.L., Gaseous Bromine : and particulate Lead, vanadium, and Bromine in a polluted Atmosphere; Env. Sci. \& Tech., 6 (1), 69-71 (1972).

Pierrard, H.M.. Photochemical Decomposition of Lead Halides from Auto- ' mobile Exhaust. Env. Sci. \& Tech., 3 (1), 48-51 (1969).

Robbins, J.A.. Suitz, F.I., Bromine and Chlorine Loss from Lead Balide Automobile Exhaust particulates, Env. Sci. F Tech.. 6 (2), 164-169 (1972).

Ter Haar, G.L., Levane, D.L., Ha, J.N., Brandt, M., Composition, Size and control of Automotive Exhaust Particulates, J. Air. Poll. Control Assoe., 22 (1), 39-46 (1972) . 